\title{
Management of Potato Post Harvest Tuber Rots by Some Organic Acids and Essential Plant Oils
}

\author{
Attia, M.F.; Abada, K.A.; Naffa, A.M.A.K and \\ Boghdady, S.F.
}

1- Plant Pathology Department, Faculty of Agriculture, Cairo University, Giza, Egypt.

2- Plant Pathology Research Institute, Agricultural Research Center, Giza, Egypt.

$D^{\mathbf{r y}}$ and white rots incited by Fusarium solani and Sclerotinia sclerotiorum are responsible to cause the major postharvest losses in potato tubers cv. "Spunta" during cold storage. Isolation trials from potato tubers showing rot symptoms collected from local markets yielded forty-one fungal isolates belonging to six genera. The isolated fungi were purified and identified as Fusarium solani (nine isolates), F. semitectum (seven isolates), Sclerotinia sclerotiorum (six isolates), Alternaria sp. (six isolates), F. oxysporum, (five isolates), Rhizoctonia solani (three isolates), and Penicillium sp. (two isolates). Pathogenicity tests showed that $F$. solani and $S$. sclerotiorum were the most pathogenic fungi. The inhibitory effect of organic acids (boric, oxalic and salicylic acids) on the linear growth of $F$. solani and $S$. sclerotiorum in vitro showed that the tested organic acids resulted in different degrees of inhibition to the mycelial growth of the two tested fungi compared with control treatment. This inhibition was gradually increased by increasing the concentration of the tested organic acids. In addition, oxalic acid resulted in $100 \%$ inhibition to the mycelial growth of the two tested pathogens at $0.4 \%$ concentration. The other organic acids gave intermediate inhibition. The effect of camphor oil (Eucalyptus glabulus), black seed (Nigella sativa), garlic and spearmint oils against Fusarium solani and Sclerotinia sclerotiorum, in vitro and in vivo on tubers during cold storage was determined. Fusarium solani, F. semitectum and Sclerotinia sclerotiorum were completely inhibited by the application of spearmint oil concentrations at 0.3 and $0.4 \%$, in vitro. In vivo results showed also that Nigella sativa preparation was the most effective as it completely suppressed disease severity\% caused by Fusarium solani and Sclerotinia sclerotiorum $(0.0 \%)$ followed by Camphor oil during cold storage. Essential oils maintained highest tubers quality sprouting and reduced weight losses. Generally, treatment with both organic acids and essential plant oils gave effective control for the two pathogens and reduced the loss in fresh weight of potato tubers in addition to reducing the sprout of the tubers during cold storage at $13^{\circ} \mathrm{C}$ for two months. 
Keywords: Potato, Solanum tuberosum, post-harvest tuber-rots, essential plant oils, camphor oil, black seed oil, garlic oil, spearmint oil, organic acids, salicylic acid, boric acid, oxalic acid, quality parameters of storage tubers.

Potato (Solanum tuberosum L.) is known as one of the most important crops overall the world. It is ranked as the fourth main food crop after wheat, maize and rice (Hawkes, 1994). The world production of potato reached about 368 million ton, of which 4.8 million tons are produced in Egypt (FAOSTAT, 2013).

Potato tubers are liable to infection by many fungi during storage leading to great loss in quantity and quality. One of the most common fungal diseases on potatoes is dry-rot causedby Fusarium solani (Jensen et al., 2011 and Naffa, 2012) and whiterot caused by Sclerotinia sclerotiorum (Catherino et al., 2000; Siviero and Motton 2000 and Mansour and Naffa, 2005).

Potato dry-rot disease leads to significant losses in both quality and quantity of potato tubers. The causal pathogen kills potato sprouts and reduces crop establishment, when the crop losses reached up to $25 \%$ in the field and may be reached more than $60 \%$ of tubers during storage (Ghadiri et al., 2013).

Up to date, thirteen species of genus Fusarium were found to be the causals of potato dry-rot around the world. In this concern, the most important Fusarium spp. are $F$. solani, F. sambucinum and $F$. avenaceum. In North America and parts of Europe, $F$. sambucinum and $F$. coeruleum are considered to be the most significant causal agents of potato tuber dry-rot. In Britain, $F$. coeruleum is more prevalent, meanwhile in Iran and South Africa, F. solani is the main causal species of potato dry-rot (Chehri et al., 2011).

In Egypt, potato occupies an important position among all vegetable crops, and it is the second vegetable crop after tomato and the first for exportation.

Several strategies for controlling post-harvest potato tuber fungal diseases have been introduced over the years but serious losses still occur, largely because the effectiveness of these approaches is variable and often short lived (Benhamou et al., 1994). Current thinking about plant protection and the environment suggests alternatives to pesticides (Liu et al., 1995), so in this study, induced resistance was used for controlling plant diseases (Abd-El-Kareem, 2007)

Benzoic acid, salicylic acid and tannic acid have direct antifungal activity on Fusarium solani, F. oxysporum and F. moniliforme on media (Galal et al., 2000).

Lui and Kushalappa, (2002) indicated that dry rot of potatoes causes significant yield loss in storage and may also produce mycotoxins and reduce plant yield and tuber quality.

Egypt. J. Phytopathol., Vol. 47, No. 1 (2019) 
Elbashir et al. (2011) revealed that spearmint oil was efficient treatment in reducing the sprouting and weight loss of two potato varieties (Diamant and Sinora). Also,Samane and Aminifard (2012) and Mohammadi (2012) found that application of the essential oils of ammi (Carum copticum) and anise (Pimpinella anisum) significantly increased the shelf life and inhibited the grey mould growth on tomato fruits completely in comparison to control .

The objective of this work is to study the effect of some organic acids and plant oils on protecting potato tubers from white and dry rots caused by Sclerotinia sclerotiorum and Fusarium solani and maintaining quality of tubers during storage at $13^{\circ} \mathrm{C}$ for two months.

\section{Materials and Methods}

1- Isolation, purification and identification the isolated fungi from potato tubers showing rot symptoms collected from local markets:

Potato tubers showing post-harvest rot symptoms collected from the local markets were used to isolate the associated fungi with tuber rot. The infected tubers were thoroughly washed in running tap water and the infected parts were cut into small pieces with lesions having half healthy and half diseased tissue. The pieces were surface sterilized in $2 \%$ sodium hypochlorite for two minutes. The tissue pieces were subsequently washed in three changes of sterilized water to eliminate excess sodium hypochlorite then the pieces were transferred onto PDA medium in Petri-plates. The plates were incubated at $25 \pm 2{ }^{\circ} \mathrm{C}$ and observed periodically for growth of the emerged fungi. The isolated fungi were purified by hyphal tip method and/ or single spore technique and maintained on PDA slants .The purified fungi were identified on the basis of cultural, morphological characteristics using the descriptions of Booth (1971) and Domsch et al. (1980).

2- Pathogenicity test of the isolated fungi:

The purified fungi were tested for their pathogenicity on apparently healthy potato tubers (cv. Spunta), selected from local retail stores.

Apparently healthy and uniform in size potato tubers, cv. Spunta, were used in all pathogenicity tests. Tubers were held and sterilized as mentioned before. then inoculated by each of Fusarium solani, F. semitectum, F. oxysporum, Sclerotinia sclerotiorum, Rhizopus stolonifer, Penicillium sp. Alternaria sp. and Rhizoctonia solani. The progress of infection was examined daily on nine replicate tubers for each isolate. The inoculated tubers were stored for 10 days at room temperature $25 \pm 2^{\circ} \mathrm{C}$ except those inoculated by S. sclerotiorum were incubated in a refrigerator at $10 \pm 2^{\circ} \mathrm{C}$.

Disease severity was calculated using a scale (0-4); where $0=$ healthy, $1=1$ $25 \%$ infection, $2=26-50 \%$ infection, $3=51-75 \%$ infection, and $4=76-100 \%$ infection, as recorded by Hanounik (1986) as follows: 


$$
\% \text { Disease Severity }=\frac{\Sigma(\mathrm{n} \times \mathrm{v})}{4 \mathrm{~N}} \times 100
$$

Where:

$\mathrm{n}=$ Number of infected tubers in each category.

$\mathrm{v}=$ Numerical values of symptoms category.

$\mathrm{N}=$ Total number of tubers.

4 = Maximum of numerical values of symptoms categories.

3- Source of the tested organic acids and the essential plant oils:

Organic acids, i.e. salicylic, boric and oxalic acids were obtained from ElGomhoria Chemical Co. Also, the essential plant oils of camphor oil (Eucalyptus glabulus), black seed (Nigella sativa), garlic and spearmint oils were obtained from Cairo Company for Oils, Cairo, Egypt.

4. Effect of the tested organic acids and the essential plant oils on the linear growth of F. solani and S. sclerotiorum in vitro:

The effect of the tested organic acids and essential plant oils on the mycelial growth of both $F$. solani and $S$. sclerotiorum was tested in vitro. The concentrations of $0.1,0.2,0.3$ and $0.4 \%$ were prepared from the tested organic acids and the essential plant oils (with $0.5 \%$ Tween 20). Each concentration was added to the calculated PDA medium, just before solidification and poured into Petri-plates. After medium solidification, plates were inoculated with 5-mm discs of 7-day-old culture of any of both fungi and incubated at $25 \pm 2{ }^{\circ} \mathrm{C}$. Three plates were used for each concentration. The linear growth was measured when the plates of the control treatment were covered with the fungal growth. Inhibition percentage of mycelial growth of the tested pathogens was calculated by the formula:

Where:

$$
\mathrm{I}=(\mathrm{C}-\mathrm{T}) / \mathrm{C} \times 100
$$

$\mathrm{I}=$ Percent of inhibition in growth of the tested pathogen.

$\mathrm{C}=$ Linear growth of the pathogen $(\mathrm{cm})$ in control.

$\mathrm{T}=$ Liner growth of the pathogen $(\mathrm{cm})$ in treatment.

5- Effect of the tested organic acids and the essential plant oils on management the infection by $F$. solani and S. sclerotiorum in vivo:

Fresh potato tubers cv. Spounta apparently free of any damage and diseases were used in this experiment. Tubers were surface sterilized with sodium hypochlorite (2\%) for $3 \mathrm{~min}$. and washed several times with sterilized water. The effect of dipping potato tubers in some organic acids and the essential plant oils during cold storage period was studied. Such effect was studied in the naturally infected (uninoculated) tubers as well as the artificially inoculated tubers with any of Fusarium solani and S. sclerotiorum. Inoculation was carried out by fungal growth disks $(3 \mathrm{~mm})$, inserted in the tuber. After 24 hours, the inoculated tubers were dipped in the given treatments. All treated tubers as well as the untreated (uninoculated and

Egypt. J. Phytopathol., Vol. 47, No. 1 (2019) 
inoculated by fungi) were stored at $13{ }^{\circ} \mathrm{C}$ for two months and $90 \%$ R.H. The stored potato tubers were examined weekly for detection of decay symptoms of both fungal pathogens. Percentages of tubers rot severity was assessed eight weeks after inoculation with any of $F$. solani and $S$. sclerotiorum. Disease severity was calculated using the formula adopted by Hanounik (1986).

6- Potato tubers quality parameters:

The potato tubers quality parameters, i.e., sprouting and loss in weight were determined in potato tubers inoculated with any of the two pathogens and uninoculated treated tubers.

a- Loss in weight:

Loss in potato tuber fresh weight \% (gm fresh weight \%) was estimated in the inoculated or uninoculated potato tubers of various treatments (average weight of 40 tubers for each treatment) according to the following equation:

\section{$b$ - Sprouting}

$$
\% \mathrm{~L} . \mathrm{W}=\frac{\text { (Initial weight }- \text { weight of potato at sampling date) }}{\text { Initial weight of potato tubers. }} \times 100
$$

Spouting level was determined according to Naffa (1995), as follow: ++++ $=100 \%$ sprouting $;+++=75 \%$ sprouting $;++=50 \%$ sprouting $;+=25 \%$ sprouting and $-=5 \%$ sprouting.

\section{7- Statistical analysis:}

All data obtained were subjected to the proper statistical analysis using the MSTAT statistical software and comparison was made following Fishers L.S.D. (0.05) as described by Song and Keane (2006).

\section{Results}

1- Isolation, purification and identification of fungi isolated from potato tubers showing rot symptoms collected from local markets:

Isolation trials from potato tubers showing rot symptoms collected from local markets yielded forty-one fungal isolates belonging to six genera. The Isolated fungi were purified and identified as Alternaria sp., Fusarium oxysporum Schlecht. emend. Snyder \& Hansen. F. semitectum Berk. \& Ravenel; F. solani (Mart.) Sacc.; Sclerotinia sclerotiorum (Lib.) de Bary; Penicillium sp., Rhizoctonia solani J.G. Kühn and Rhizopus stolonier Vuillemin. The respective percentages of their frequency were 14.6, 12.2, 17.1, 21.9, 14.6, 4.9, 7.3 and 7.3\%, respectively. The highest frequency was recorded by $F$. solani followed by $F$. semitectum, Alternaria sp. and Sclerotinia sclerotiorum, respectively. On the other hand, the fungus Penicillium sp., recorded the lowest frequency followed by both $R$. solani and $R$. stolonifer. 
Table (1): Occurrence and frequency $(\%)$ of the isolated fungi from rotted potato tubers collected from different markets.

\begin{tabular}{lcc}
\hline \multicolumn{1}{c}{ The isolated fungi } & $\begin{array}{c}\text { Occurrence of the } \\
\text { isolated fungi }\end{array}$ & \% Frequency \\
\hline Alternaria sp. & 6 & 14.6 \\
F. oxysporum & 5 & 12.2 \\
F. semitectum & 7 & 17.1 \\
Fusarium solani & 9 & 21.9 \\
Sclerotinia sclerotiorum & 6 & 14.6 \\
Penicillium sp. & 2 & 4.9 \\
Rhizoctonia solani & 3 & 7.3 \\
Rhizopus stolonifer & 3 & 7.3 \\
\hline Total & 41 & 99.9 \\
\hline
\end{tabular}

2- Pathogenicity test of the isolated fungi:

Pathogenicity test of the different isolated fungi from potato tubers (Table 2) reveal that all the tested fungi were pathogenic to the tubers at room temperature $\left(25 \pm 2{ }^{\circ} \mathrm{C}\right)$ except Sclerotinia sclerotiorum at refrigerator $\left(10+2^{\circ} \mathrm{C}\right)$ under $90-95 \%$ relative humidity (R.H.), in pored cartoon boxes for at least two months and inoculation with the tested fungi. F. solani, Sclerotinia sclerotiorum and Alternaria sp. showed the highest level of infection for potato tubers. Meanwhile, F. solani, $F$. oxysporum and $F$. semitectum recorded intermediate figures of infection, being 55.56, 36.11 and 25.0\% disease severity, respectively. However, the lowest infection on potato tubers was recorded by any of Penicillium sp. and R. stolonifer (19.44\%).

Table (2): Pathogenicity test of the isolated fungi using potato tubers (cv. Spunta), ten days after incubation at $25 \pm 2^{\circ} \mathrm{C}$. (Sclerotinia sclerotiorum) at refrigerator $10 \pm 2^{\circ} \mathrm{C}$.

\begin{tabular}{lc}
\hline \multicolumn{1}{c}{ The tested fungi } & \% Diseases severity \\
\hline F. solani & 96.67 \\
F. semitectum & 25.0 \\
F. oxysporum & 36.11 \\
S. sclerotiorum $*$ & 91.66 \\
Rhizopus stolonifer & 19.44 \\
Penicillium sp. & 19.44 \\
Alternaria sp. & 88.89 \\
Rhizoctonia solani & 55.56 \\
\hline L.S.D at 0.05 & 1.2 \\
\hline
\end{tabular}

*Potato tubers inoculated with $S$. sclerotiorum were kept in a refrigerator for ten days at $10 \pm 2^{\circ} \mathrm{C}$.

Egypt. J. Phytopathol., Vol. 47, No. 1 (2019) 
3- Effect of the tested organic acids and the essential plant oils on the linear growth of F. solani and S. sclerotiorum in vitro:

\subsection{Effect of the tested organic acids:}

Data in Table (3) show that oxalic acid and boric acid showed complete inhibition of growth of S. sclerotiorum at 0.3 and $0.4 \%$ concentrations. While, Fusarium solani showed complete inhibition of growth only due to using oxylic acid.

Table (3): Effect of different concentrations of three organic acids on the linear growth (cm) of $F$. solani and $S$. sclerotiorum in vitro.

\begin{tabular}{|c|c|c|c|c|c|}
\hline \multirow[b]{2}{*}{ Treatments } & \multirow[b]{2}{*}{$\begin{array}{c}\text { Conc. } \\
(\%)\end{array}$} & \multicolumn{2}{|c|}{ F. solani } & \multicolumn{2}{|c|}{ S. sclerotiorum } \\
\hline & & $\begin{array}{l}\text { Linear } \\
\text { growth } \\
(\mathrm{cm})\end{array}$ & $\begin{array}{c}\% \\
\text { Efficacy }\end{array}$ & $\begin{array}{l}\text { Linear } \\
\text { growth } \\
(\mathrm{cm})\end{array}$ & $\begin{array}{c}\% \\
\text { Efficacy }\end{array}$ \\
\hline \multirow{5}{*}{ Boric acid } & 0.1 & 5.92 & 34.22 & 1.2 & 86.56 \\
\hline & 0.2 & 5.25 & 41.67 & 0.33 & 96.33 \\
\hline & 0.3 & 3.92 & 56.44 & 0.00 & 100.00 \\
\hline & 0.4 & 3.33 & 63.00 & 0.00 & 100.00 \\
\hline & Mean & 4.61 & & 0.38 & \\
\hline \multirow{5}{*}{ Oxalic acid } & 0.1 & 4.92 & 45.33 & 3.19 & 64.56 \\
\hline & 0.2 & 3.92 & 56.44 & 1.5 & 83.33 \\
\hline & 0.3 & 0 & 100.00 & 0.00 & 100.00 \\
\hline & 0.4 & 0 & 100.00 & 0.00 & 100.00 \\
\hline & Mean & 2.21 & & 1.17 & \\
\hline \multirow{5}{*}{ Salicylic acid } & 0.1 & 5.5 & 38.89 & 2.67 & 70.33 \\
\hline & 0.2 & 4.33 & 51.89 & 2.33 & 74.11 \\
\hline & 0.3 & 4.12 & 54.22 & 1.12 & 86.56 \\
\hline & 0.4 & 2.67 & 70.33 & 0.33 & 96.33 \\
\hline & Mean & 4.16 & & 1.61 & \\
\hline Control & & 9 & 0 & 9 & 0 \\
\hline \multicolumn{6}{|l|}{ L.S.D at $0.05 \%$} \\
\hline Treatment $(\mathrm{T})$ & & 0.6 & & 0.43 & \\
\hline Concentration (C) & & 0.77 & & 0.55 & \\
\hline $\mathrm{T} \times \mathrm{C}$ & & 1.34 & & 0.95 & \\
\hline
\end{tabular}

\subsection{Effect of the essential plant oils:}

Data in Table (4) indicate that spearmint oil was able to reduce the mycelial growth of Fusarium solani at concentrations $0.2,0.3,0.4 \%$, also, black seed oil was able to reduce the mycelial growth of Fusarium solani at concentrations 0.3 and $0.4 \%$, while garlic oil was less effective in reducing growth of Fusarium solani of the same plant oils followed by camphor oil. The effect of these plant oils in reducing the growth of the tested pathogen in comparison with control treatment. 
Spearmint oil and camphor oil were the best among all tested plant oils where their tested concentrations reduced the growth of the tested pathogen, $S$. sclerotiorum to $100 \%$. While black seed oil was less effective on growth of the same pathogenic fungi at all different concentrations, followed by garlic oil. The effect of these plant oils in reducing the growth of the tested pathogen was more pronounced in comparison with control treatment.

Table (4): Effect of four essential plant oils on the linear growth of $F$. solani and S. sclerotiorum in vitro.

\begin{tabular}{|c|c|c|c|c|c|}
\hline \multirow[b]{2}{*}{$\begin{array}{c}\text { Essential plant } \\
\text { oils }\end{array}$} & \multirow[b]{2}{*}{ Conc. $\%$} & \multicolumn{2}{|c|}{ F. solani } & \multicolumn{2}{|c|}{ S. sclerotiorum } \\
\hline & & $\begin{array}{l}\text { Linear } \\
\text { growth } \\
(\mathrm{cm})\end{array}$ & $\begin{array}{c}\% \\
\text { Efficacy }\end{array}$ & $\begin{array}{l}\text { Linear } \\
\text { growth } \\
(\mathrm{cm})\end{array}$ & $\begin{array}{c}\% \\
\text { Efficacy }\end{array}$ \\
\hline \multirow{5}{*}{ Garlic } & 0.1 & 9.00 & 0.00 & 2.83 & 68.52 \\
\hline & 0.2 & 8.67 & 3.67 & 1.91 & 78.76 \\
\hline & 0.3 & 7.67 & 14.78 & 1.33 & 85.22 \\
\hline & 0.4 & 7.00 & 22.67 & 0.00 & 100.00 \\
\hline & Mean & 8.10 & & 1.52 & \\
\hline \multirow{5}{*}{ Camphor } & 0.1 & 6.15 & 31.67 & 0.00 & 100.00 \\
\hline & 0.2 & 4.50 & 50.00 & 0.00 & 100.00 \\
\hline & 0.3 & 3.17 & 64.81 & 0.00 & 100.00 \\
\hline & 0.4 & 2.68 & 70.22 & 0.00 & 100.00 \\
\hline & Mean & 4.13 & & 0.00 & \\
\hline \multirow{5}{*}{ Spearmint } & 0.1 & 5.48 & 39.17 & 0.00 & 100.00 \\
\hline & 0.2 & 0.00 & 100.00 & 0.00 & 100.00 \\
\hline & 0.3 & 0.00 & 100.00 & 0.00 & 100.00 \\
\hline & 0.4 & 0.00 & 100.00 & 0.00 & 100.00 \\
\hline & Mean & 1.37 & & 0.00 & \\
\hline \multirow{5}{*}{ Nigella sativa } & 0.1 & 9.00 & 0.00 & 7.60 & 63.52 \\
\hline & 0.2 & 7.60 & 15.56 & 7.50 & 80.93 \\
\hline & 0.3 & 0.00 & 100.00 & 7.00 & 81.67 \\
\hline & 0.4 & 0.00 & 100.00 & 0.00 & 100.00 \\
\hline & Mean & 4.15 & & 5.53 & \\
\hline Control & & 9.00 & 0.00 & 9.00 & 0.00 \\
\hline \multicolumn{6}{|l|}{ L.S.D at 0.05} \\
\hline Oils (O) & & 0.19 & & 0.16 & \\
\hline Conc. (C) & & 0.17 & & 0.19 & \\
\hline $\mathrm{O} \times \mathrm{C}$ & & 0.39 & & 0.32 & \\
\hline
\end{tabular}

Egypt. J. Phytopathol., Vol. 47, No. 1 (2019) 
4- Effect of the tested organic acids and the essential plant oils on the severity of infection by F. solani and S. sclerotiorum in vivo:

4.1. Effect of the tested organic acids:

Data in Table (5) indicate that the three tested organic acids significantly reduced the severity of infection by $F$. solani and S. sclerotiorum comparing with control treatment in vivo.

Table (5): Effect of three organic acids on the severity of infection by $F$. solani and $S$. sclerotiorum on potato tubers.

\begin{tabular}{|c|c|c|c|c|c|}
\hline \multirow[b]{2}{*}{ Treatments } & \multirow{2}{*}{$\begin{array}{c}\text { Conc. } \\
\%\end{array}$} & \multicolumn{2}{|c|}{ F. solani } & \multicolumn{2}{|c|}{ S. sclerotiorum } \\
\hline & & $\begin{array}{c}\% \text { Disease } \\
\text { severity }\end{array}$ & $\begin{array}{c}\% \\
\text { Efficacy }\end{array}$ & $\begin{array}{c}\% \text { Disease } \\
\text { severity }\end{array}$ & $\%$ Efficacy \\
\hline \multirow{4}{*}{ Boric acid } & 0.2 & 3.78 & 58.76 & 25 & 35.72 \\
\hline & 0.3 & 2.31 & 97.48 & 22.22 & 42.86 \\
\hline & 0.4 & 0.00 & 100.00 & 19.44 & 50.01 \\
\hline & Mean & 2.03 & & 22.22 & \\
\hline \multirow{4}{*}{ Oxalic acid } & 0.2 & 1.95 & 97.98 & 27.8 & 92.85 \\
\hline & 0.3 & 0.92 & 98.99 & 0.0 & 100.00 \\
\hline & 0.4 & 0.00 & 100.00 & 0.0 & 100.00 \\
\hline & Mean & 0.96 & & 9.27 & \\
\hline \multirow{4}{*}{ Salicylic acid } & 0.2 & 11.11 & 87.9 & 22.22 & 42.86 \\
\hline & 0.3 & 5.56 & 93.93 & 8.33 & 78.58 \\
\hline & 0.4 & 4.63 & 94.95 & 5.56 & 85.70 \\
\hline & Mean & 7.10 & & 12.04 & \\
\hline Control & 0.0 & 91.66 & 0.00 & 38.84 & 0.00 \\
\hline \multicolumn{6}{|l|}{ L.S.D at $0.5 \%$} \\
\hline \multirow{2}{*}{\multicolumn{2}{|c|}{$\begin{array}{l}\text { Organic acids }=(\mathrm{T}) \\
\text { Concentration }=(\mathrm{C})\end{array}$}} & 0.25 & & 0.42 & \\
\hline & & 0.29 & & 0.48 & \\
\hline \multicolumn{2}{|c|}{$\mathrm{T} \times \mathrm{C}$} & 0.50 & & 0.83 & \\
\hline
\end{tabular}

4.2. Effect of the tested essential plant oils:

Data in Table (6) prove that disease severity \% caused by either Fusarium solani or S. sclerotiorum was significantly decreased by all tested preparations comparing to the untreated control. The Disease severity \% caused by both pathogens was significantly lower at 1.0 than at 0.5 concentrations. Camphor oil and Nigella sativa oil at both concentrations inhibited completely the infection of potato tubers with $F$. solani, while the infection of potato tubers cv. Spunta with Sclerotinia sclerotiorum was inhibited at $1 \%$ conc. in the garlic and camphor oils. Also, the results cleared that Nigella sativa treatment at both concentrations inhibited completely disease symptoms and prevented completely the infection of potato tubers caused by Sclerotinia sclerotiorum. 
Table (6): Effect of four essential plant oils on severity of infection by $F$. solani and S. sclerotiorum

\begin{tabular}{|c|c|c|c|c|c|}
\hline \multirow[b]{2}{*}{ Treatment } & \multirow{2}{*}{$\begin{array}{c}\text { Conc. } \\
\%\end{array}$} & \multicolumn{2}{|c|}{ F. solani } & \multicolumn{2}{|c|}{ S. sclerotiorum } \\
\hline & & $\begin{array}{c}\text { \% Disease } \\
\text { severity }\end{array}$ & $\begin{array}{c}\% \\
\text { Efficacy }\end{array}$ & $\begin{array}{c}\% \text { Disease } \\
\text { severity }\end{array}$ & $\begin{array}{c}\% \\
\text { Efficacy }\end{array}$ \\
\hline \multirow{3}{*}{ Garlic } & 0.5 & 5.56 & 71.39 & 27.78 & 49.99 \\
\hline & 1.0 & 2.78 & 85.69 & 0.00 & 100.00 \\
\hline & Mean & 4.17 & & 13.89 & \\
\hline \multirow{3}{*}{ Camphor } & 0.5 & 0.00 & 100 & 5.56 & 89.99 \\
\hline & 1.0 & 0.00 & 100 & 0.00 & 100.00 \\
\hline & Mean & 0.00 & & 2.78 & \\
\hline \multirow{3}{*}{ Spearmint } & 0.5 & 13.89 & 28.55 & 11.11 & 80.00 \\
\hline & 1.0 & 2.78 & 85.69 & 8.36 & 84.95 \\
\hline & Mean & 8.34 & & 9.74 & \\
\hline \multirow{3}{*}{ Nigella sativa } & 0.5 & 0.00 & 100 & 0.00 & 100.00 \\
\hline & 1.0 & 0.00 & 100 & 0.00 & 100.00 \\
\hline & Mean & 0.00 & & 0.00 & \\
\hline Control & & 19.44 & 0.00 & 55.56 & 0.00 \\
\hline \multicolumn{6}{|l|}{ L.S.D at 0.05} \\
\hline Plant oils (P) & & 0.33 & & 0.28 & \\
\hline Conc. (C) & & 0.21 & & 0.18 & \\
\hline $\mathrm{P} \times \mathrm{C}$ & & 0.47 & & 0.40 & \\
\hline
\end{tabular}

5- Effect of the tested organic acids and the essential plant oils on the severity of the natural infection by tuber rots in vivo:

\subsection{Effect of the tested organic acids:}

Data in Table (7) show the effect of post-harvest treatments with three organic acids, i.e., boric, oxalic and salicylic acids at 0.2 and $0.3 \%$ on the natural infection of potato tubers by rots eight weeks after storage. Immersing the tubers in the concentration of $0.2 \%$ of any of the three tested organic acids resulted in 22.22 , 14.81 and $7.41 \%$ infection, respectively. Meanwhile, no infection by tuber rots was occurred by immersing the tubers in $0.3 \%$ concentration of any of the three tested organic acids up to eight weeks of cold storage at $13^{\circ} \mathrm{C}$. Control treatment recorded $47.61 \%$ infection.

\subsection{Effect of the tested essential plant oils:}

Data in Table (8) show the effect of potato tubers treatment with essential oils, i.e., garlic, camphor, spearmint and $N$. sativa on natural infection of potato tubers after two months storage. Camphor and spearmint oils showed the highest efficacy $(100 \%)$ at concentrations 0.5 or $1.0 \%$ on potato tubers compared with the control $(0.0)$.

Egypt. J. Phytopathol., Vol. 47, No. 1 (2019) 
Table (7): Effect of potato tubers treatment with certain organic acids on infection with tuber rots under natural conditions.

\begin{tabular}{lccc}
\hline \multicolumn{1}{c}{ Treatments } & Conc. $(\%)$ & \% Infection & \% Efficacy \\
\hline \multirow{3}{*}{ Boric acid } & 0.2 & 22.22 & 53.33 \\
& 0.3 & 0.00 & 100.00 \\
\cline { 2 - 4 } & Mean & 11.11 & \\
\hline \multirow{3}{*}{ Oxalic acid } & 0.2 & 14.81 & 68.89 \\
& 0.3 & 0.00 & 100.00 \\
\cline { 2 - 4 } & Mean & 7.41 & 84.44 \\
Salicylic acid & 0.2 & 7.41 & 100.00 \\
\cline { 2 - 4 } Control & 0.3 & 0.00 & - \\
\hline L.S.D at 0.5\% & 0.0 & 3.71 & \\
Organic acids & $=(\mathrm{T})$ & 47.61 & \\
Concentration & $=(\mathrm{C})$ & & \\
$\mathrm{T} \times \mathrm{C}$ & & 0.36 & \\
\hline
\end{tabular}

Table (8): Effect of four essential plant oils on natural infection of potato tubers with rots.

\begin{tabular}{|c|c|c|c|}
\hline Treatment & Conc. $(\%)$ & $\begin{array}{l}\% \text { Disease } \\
\text { infection }\end{array}$ & Efficacy \\
\hline \multirow{3}{*}{ Garlic } & 0.5 & 2.31 & 87.53 \\
\hline & 1.0 & 0.92 & 95.03 \\
\hline & Mean & 1.62 & \\
\hline \multirow{3}{*}{ Camphor } & 0.5 & 0.00 & 100.00 \\
\hline & 1.0 & 0.00 & 100.00 \\
\hline & Mean & 0.00 & \\
\hline \multirow{3}{*}{ Spearmint } & 0.5 & 0.00 & 100.00 \\
\hline & 1.0 & 0.00 & 100.00 \\
\hline & Mean & 0.00 & \\
\hline \multirow{3}{*}{ Nigella sativa } & 0.5 & 5.56 & 69.98 \\
\hline & 1.0 & 3.70 & 80.02 \\
\hline & Mean & 4.63 & \\
\hline Control & & 18.52 & 0.00 \\
\hline \multicolumn{4}{|l|}{ L.S.D at 0.05} \\
\hline \multicolumn{2}{|c|}{ Plant oils (O) } & 0.28 & \\
\hline \multicolumn{2}{|c|}{ Concentrations (C) } & 0.17 & \\
\hline \multicolumn{2}{|c|}{$\mathrm{O} \times \mathrm{C}$} & 0.39 & \\
\hline
\end{tabular}


6.1. Effect of the tested organic acids and the essential plant oils on the loss in tubers weight in vivo:

6.1. Effect of the tested organic acids:

Data in Table (9) indicate that boric, oxalic and salicylic acids concentrations at $0.2,0.3,0.4 \%$ reduced the weight loss of naturally infected potato tubers more than those artificially infected by $F$. solani and $S$. sclerotiorum during storage at $13^{\circ} \mathrm{C}$ for two months.

The losses in fresh weight of potato tubers during cold storage were lower than in control. Such loss in weight was highly increased in untreated tubers during storage for two months.

Table (9): Effect of three organic acids on weight loss of potato tubers artificially infected by $F$. solani and $S$. sclerotiorum or naturally infected after two months storage.

\begin{tabular}{lcccc}
\hline \multirow{2}{*}{ Treatments } & $\begin{array}{c}\text { Conc. } \\
(\%)\end{array}$ & F. solani & S. sclerotiorum & $\begin{array}{c}\text { Natural } \\
\text { infection }\end{array}$ \\
\hline \multirow{3}{*}{ Boric acid } & 0.2 & 5.5 & 5.1 & 3.3 \\
& 0.3 & 4.75 & 4.0 & 2.0 \\
& 0.4 & 3.75 & 3.2 & 1.2 \\
\cline { 2 - 5 } & Mean & 4.67 & 4.1 & 2.17 \\
\hline \multirow{3}{*}{ Oxalic acid } & 0.2 & 3.33 & 2.2 & 1.1 \\
& 0.3 & 2.4 & 1.0 & 0.5 \\
& 0.4 & 1.78 & 0.5 & 0.1 \\
\cline { 2 - 5 } & Mean & 2.50 & 1.23 & 0.57 \\
\hline \multirow{3}{*}{ Salicylic acid } & 0.2 & 5.0 & 4.23 & 2.1 \\
& 0.3 & 4.44 & 3.11 & 1.11 \\
& 0.4 & 3.20 & 1.84 & 0.99 \\
\hline Control & Mean & 4.21 & 3.06 & 1.4 \\
\hline
\end{tabular}

\subsection{Effect of the tested essential plant oils:}

Data in Table (10) indicate that garlic, camphor, spearmint and Nigella sativa oils at concentrations 0.5 or $1.0 \%$ reduced the weight loss of potato tubers either naturally infected or artificially inoculated with $F$. solani and $S$. sclerotiorum during the cold storage at $13^{\circ} \mathrm{C}$ for 2 months.

The losses in fresh weight of potato tubers during cold storage were lower than in control. Such loss in weight was highly increased in untreated tubers during storage for two months.

Egypt. J. Phytopathol., Vol. 47, No. 1 (2019) 
Table (10): Effect of four essential plant oils on weight loss of potato tubers artificially infected with each of Fusarium solani, Sclerotinia sclerotiorum and or left to natural infection and stored for two months.

\begin{tabular}{lcccc}
\hline \multirow{2}{*}{ Treatment } & $\begin{array}{c}\text { Conc. } \\
(\%)\end{array}$ & F. solani & $\begin{array}{c}\text { S. } \\
\text { sclerotiorum }\end{array}$ & $\begin{array}{c}\text { Natural } \\
\text { infection }\end{array}$ \\
\hline \multirow{2}{*}{ Garlic } & 0.5 & 8.00 & 7.00 & 1.06 \\
& 1.0 & 7.50 & 5.50 & 0.43 \\
\cline { 2 - 5 } & Mean & 7.75 & 6.25 & 0.99 \\
\hline \multirow{2}{*}{ Camphor } & 0.5 & 7.00 & 4.50 & 0.27 \\
& 1.0 & 7.00 & 4.00 & \\
\cline { 2 - 5 } Spearmint & Mean & 7.00 & 4.25 & 1.36 \\
\hline \multirow{2}{*}{ Nigella sativa } & 0.5 & 7.00 & 5.50 & 4.25 \\
& 1.0 & 6.49 & 5.50 & 2.35 \\
\cline { 2 - 5 } & Mean & 6.75 & 5.50 & 6.10 \\
\hline Control & 0.5 & 5.07 & 4.70 & \\
\hline
\end{tabular}

7- Effect of the tested organic acids and the essential plant oils on sprouting the tubers in vivo:

\subsection{Effect of the tested organic acids:}

Data presented in Table (11) show that all organic acid treatments resulted in reducing tubers sprouting during storage period. In general, the percentages of tubers sprout were higher in potato tubers inoculated with $F$. solani and S. sclerotiorum than those left to the natural infection either treated with the tested organic acids or of control treatment. Sprouting, being 5\% was occurred when the inoculated tubers with the two pathogenic fungi and the naturally infected were treated with $0.4 \%$ of oxalic acid, in addition, with boric and salicylic acids at $0.4,5 \%$ sprouting was occurred when the naturally infected tubers were treated with 0.3 and $0.4 \%$ of oxalic and salicylic acid, but with boric acid at $0.4 \%$. Sprouting, was (-) in natural and artificial infection compared to the control $(+++$ and ++++$)$ followed by boric acid and salicylic acid at the same concentration.

\subsection{Effect of the tested essential plant oils:}

Data in Table (12) show that all treatments decreased sprouting potato tubers compared with the control. Garlic, camphor, spearmint and N. sativa oils decreased sprouting (-) of naturally infected tubers while, $N$. sativa oil increased sprouting $(+++)$ at concentration $0.5 \%$ and decreased it $(+)$ at concentration $1.0 \%$. Infection by Fusarium solani, S. sclerotiorum highly increased sprouting (++++) compared with natural infection $(+++)$. 
Table (11): Effect of three organic acids on sprouting of potato tubers artificially inoculated with $F$. solani, $S$. sclerotiorum or left to natural infection and stored for two months.

\begin{tabular}{lcccc}
\hline \multicolumn{1}{c}{ Treatments } & Cons. & F. solani & S. sclerotiorum & $\begin{array}{c}\text { Natural } \\
\text { infection }\end{array}$ \\
\hline \multirow{3}{*}{ Boric acid } & 0.2 & ++ & ++ & + \\
& 0.3 & ++ & ++ & + \\
& 0.4 & + & + & - \\
\hline \multirow{2}{*}{ Oxalic acid } & 0.2 & + & + & + \\
& 0.3 & + & - & - \\
\hline \multirow{2}{*}{ Salicylic acid } & 0.4 & - & ++ & - \\
& 0.2 & ++ & ++ & - \\
\hline Control & 0.3 & ++ & + & +++ \\
\hline
\end{tabular}

$++++=100 \%$ sprout, $+++=75 \%$ sprout, $++=50 \%$ sprout,$+=25 \%$ sprout and $=5 \%$ sprouting.

Table (12): Effect of four essential plant oils on sprouting potato tubers infected by $F$. solani and $S$. sclerotiorum and/or left under the natural infection two months after storage.

\begin{tabular}{|c|c|c|c|c|}
\hline Treatment & $\begin{array}{c}\text { Cons. } \\
(\%)\end{array}$ & F. solani & S. sclerotiorum & $\begin{array}{c}\text { Natural } \\
\text { infection }\end{array}$ \\
\hline \multirow{2}{*}{ Garlic } & 0.50 & +++ & + & - \\
\hline & 1.00 & ++ & - & - \\
\hline \multirow{2}{*}{ Camphor } & 0.50 & + & - & - \\
\hline & 1.00 & ++ & + & - \\
\hline \multirow{2}{*}{ Spearmint } & 0.50 & + & - & - \\
\hline & 1.00 & + & - & - \\
\hline \multirow{2}{*}{ Nigellasativa } & 0.50 & - & - & +++ \\
\hline & 1.00 & - & - & + \\
\hline Control & & ++++ & ++++ & +++ \\
\hline
\end{tabular}

$++++=100 \%$ sprouting, $+++=75 \%$ sprouting, $++=50 \%$ sprouting, $+=25 \%$ sprouting and $-=5 \%$ sprouting.

\section{D i s c us s i on}

Potato is one of the most important vegetable crops in the world including Egypt. Potato plants are attacked by several plant pathogens causing serious diseases during the growing season and postharvest season (El-Gamal et al., 2007 and Abd-El-Kareem et al., 2013). Controlling of such diseases mainly depends on fungicides treatments. However, fungicidal applications cause Egypt. J. Phytopathol., Vol. 47, No. 1 (2019) 
hazards to human health. Due to this, there is an increasing interest to find new strategies of fungicides alternative for using in plant disease control systems (ElMohamedy and Abd-El-Latif 2015).

During the progress of this study, forty-one isolates of different fungi were isolated from naturally infected potato tubers collected from different localities and markets. The highest number of isolated fungi was recorded from potato tubers, i.e., F. solani, F. semitectum, Sclerotinia sclerotiorum and Alternaria sp. On the other hand, Penicillium sp, Rhizopus stolonifer and Rhizoctonia solani, recorded low frequency. Vitale et al. (1999) mentioned that Fusarium solani var. coeruleum is the most important causal agent, followed by $F$. sambucinum, $F$. avenaceum. Secor et al. (1992) reported that Fusarium causes diseases in several crops, including potato where it can cause seed decay, wilt, and dry rot decay of potato in storage.

The pathogenicity of the isolated fungi, Fusarium solani, Sclerotinia sclerotiorum, and Alternaria sp. showed the highest level of infection for potato tuber rots. While Rhizoctonia solani and $F$. oxysporum showed the medium level of infection for potato tuber rots followed by $F$. semitectum. However, the lowest infection of potato tuber rots was recorded by Penicillium sp. and Rhizopus stolonifer. Lenc et al. (2008) found that the most frequently isolated fungi causing potato dry rot were Fusarium spp., F. sambucinum ( $F$. sulphureum), F. solani, ( $F$. coeruleum), F. oxysporum F.avenaceum, $F$. culmorum and $F$. equiseti. Their pathogenicity towards potatoes varies in different parts of the world and so the designation of individual species as the main cause of disease is difficult and Han et al. 2013, recorded the first report of Sclerotinia sclerotiorum in Korea.

In vitro, oxalic, and boric acids showed complete inhibition of growth of $S$. sclerotiorum at tested concentrations, $0.3,0.4 \%$. While salicylic acid was less effective on the growth of $S$. sclerotiorum at all concentrations. It was clear from the obtained results that $S$. sclerotiorum was the most sensitive among all tested pathogens to oxalic and boric acids with their concentrations while Fusarium solani was the least sensitive one. Also, it was clear that increasing the concentration of the tested acids (oxalic and boric), 0.3 and $0.4 \%$ increased gradually the effect of these acids in reducing the growth of tested pathogens. Panahirad et al. (2012) and Rashied, (2008) found that salicylic acid at $0.25 \%$ completely suppressed the Fusarium growth in vitro.

In vivo, boric, salicylic, and oxalic acids reduced disease severity on artificial inoculation with Fusarium solani or S. sclerotiorum and natural infection of potato tuber rots comparing with control. Rashied (2008) found that dry rot of potatoes reduced naturally infected or artificially inoculated by both ascorbic and salicylic acid particularly at $2 \%$ concentration during storage at $10^{\circ} \mathrm{C}$ for 90 days or $20^{\circ} \mathrm{C}$ for 45 days. The severity of infection of potatoes with dry rot was reduced close to zero by ascorbic and salicylic acids especially during storage at $10^{\circ} \mathrm{C}$. Ascorbic acid was more effective than salicylic acid. 
The in vitro results indicated that all tested plant oils reduced the growth of selected potato rots pathogens causing tuber rots i.e., F. solani and S. sclerotiorum. Morsy, et al. (2000) reported that plant extracts of garlic and onion reduced linear growth of $F$. oxysporum, $F$. solani and $S$. rolfsii.

In vivo, spraying of black seed, spearmint, garlic and camphor oils were sprayed on potato tubers cv. spunta two times before storage at concentrations of $0.5 \%$ and $1.0 \%$ to control dry rot caused by Fusarium solani and white rot caused by Sclerotinia sclerotiorum. Rashied (2008) found that cinnamon and carnation oils at $0.25 \%$ and $0.5 \%$ inhibited the dry rot on potato tubers kept at $10^{\circ} \mathrm{C}$ under $85-90 \%$ RH for 90 days, while high infection with dry rot was found on tubers of either naturally infected or artificially inoculated tubers by all tested isolates of Fusarium spp. Similar trend of high inhibitory effect was obtained when potato tubers treated with cinnamon and carnation oils were stored at $20^{\circ} \mathrm{C}$ under $85-90 \% \mathrm{RH}$ for 45 days.

Treating potato tubers with salicylic, boric and oxalic acids at concentrations of $0.2,0.3,0.4 \%$ resulted in different degrees of reduction in the severity of tuber-rot caused by $F$. solani and $S$. sclerotiorum after storing for two months, compared to the control.

Hilal et al. (2006) found that salicylic and oxalic acid prevented the linear growth of $S$. sclerotiorum at the high concentration (1500 ppm) Also, (Naffa et al., 2006) indicated that thiourea, propyl parapen, bytylated hydroxylanisole and bytylated hydroxy toluene were significantly effective against Sclerotinia sclerotiorum on PDA medium.

Post-harvest treatment lowered the loss in fresh weight and sprouting of potato tubers, naturally and artificially inoculated with Fusarium solani and S. sclerotiorum during storage. All treatments performance to decrease of sprouting potato tubers compared with the control. Oxalic acid decreased sprouting (-) of artificially inoculated tubers with Fusarium solani, Sclerotinia sclerotiorum and naturally infected at $0.4 \%$ concentration. Control untreated with organic acids and infected with Fusarium solani, Sclerotinia sclerotiorum increased sprouting (++++) compared with the control of natural infection (+++). Generally, organic acids decreased sprouting in tubers infected with Sclerotinia sclerotiorum followed by naturally infected and those infected by Fusarium solani, respectively. Plant oil treatments performance to decrease sprouting potato tubers compared with the control. Garlic, camphor, spearmint, and Nigella sativa oils showed No sprouting (-) of naturally infected while, Nigella sativa increased sprouting (+++) at $0.5 \%$ concentration and (+) at $1.0 \%$ concentration. Infection by Fusarium solani, Sclerotinia sclerotiorum highly increase sprouting $(++++)$ compared with natural infection (+++). Eisa et al., (2010) illustrated those plant oils, i.e., thymol, anisol, eugenol, camphor oil and fennchone oils were effective in reducing the infection and disease severity percentages on detached pods infected with $S$. sclerotiorum, $B$. cinerea and $P$. aphandermatum.

Egypt. J. Phytopathol., Vol. 47, No. 1 (2019) 


\section{References}

Abd-El-Kareem, F. 2007. Potassium or sodium bicarbonates in combination with Nerol for controlling early blight disease of potato plants under laboratory, greenhouse and field conditions. Egypt. J. Phytopathol., 35: 73-86.

Abd-El-Kareem, F.; Abdel-Kader, M.M.; Fotouh, Y.O.; Abd-Alla, M.A.; El-Mougy, N.S.; El-Mohamedy, R.S. and El-Gamal, N.G. 2013. Induction of systemic resistance in faba bean against chocolate spot diseases severity using chemical inducers under field conditions. J. Applied Sci. Res., 9: 4006-4014.

Benhamou, N.; Lafontaine, P.J. and Nicole, M. 1994. Induction of systemic resistance to crown and root rot in tomato plants by seed treatment with chitosan. Phytopathology 84: 143.

Booth, C. 1971. The genus Fusarium. The Commonwealth Mycological Institute, Kew, Surrey, England. Pp: 237.

Catherino, O.C.; Carl, E.S.; Robert, N.T. and Wiliam, S.C. 2000. Variability of three isolates of Botrytis cinerea affect the inhibitory effects of calcium on this fungus. Phytopathology, 90: 769.

Chehri, K.; Mohamed, N.F.; Salleh, B. and Latiffah, Z. 2011. Occurrence and pathogenicity of Fusarium spp. on the potato tubers in Malaysia. African $J$. Agric. Res., 6(16): 3706-3712.

Domsch, K.H.; Gams, W.; and Anderson, T.H. 1980. Compendium of Soil Fungi. London: Academic Press. 859 Pp.

Eisa, N.A.; El-Habbaa, G.M.; Abdel-Mageed, M.H.; Mansour, A.S. and Ahmad, M.F. 2010. Impact of some plant oils on controlling snap bean pod mold infection and oxidative enzymes. Egypt. J. of Appl. Sci., 25(12B).

Elbashir, H.A.; Ahmed, A.H.R. and Yousif, K.S. 2011. Effect of spearmint oil on sprouting and processing quality of Diamant and Sinora potato varieties. Current Research Journal of Biological Sciences. 3(5): 530-534.

El-Gamal, N.G.; Abd-El-Kareem, F.; Fotouh, Y.O. and El-Mougy, N.S. 2007. Induction of systemic resistance in potato plants against late and early blight diseases using chemical inducers under greenhouse and field conditions. Res. J. Agric. Biol. Sci., 3: 73-81.

El-Mohamedy, R.S.R. and Abd-El-Latif, F.M. 2015. Field application of humic acid and thyme essential oil for controlling late blight disease of tomato plants under field conditions. Asian J. Plant Pathol., 9: 167-174.

FAOSTAT, 2013. Food and Agriculture Organization (FAO), http://fao.org. 
Galal, A.A.; Shaat, M.M.N. and El.Bana, A.A. 2000. Sensitivity of Alternaria redicina and Alternaria tenuissima to some antioxidant compounds. J. Agric. Sci.Mansoura univ. 25(3): 1553-1562.

Ghadiri, M.R.; Dalili, A.; Frotan, A.; Zaker, M.; Rahmanifard, B.; Dalili, M. 2013. Study on antifungal activity of some salts on growth and dry rot development of Fusarium solani (Mart) Sacc. American- Eurasian J. Agric \& Environ. Sci., 13(5): 668-672.

Han, K.S.; Kim, J.Y.; Park, J.H.; Shin, H.D. 2013. First report of Sclerotinia stem rot of anemone caused by Sclerotinia sclerotiorum in Korea. Plant Dis., 97: 99.

Hanounik, S.B. 1986. Screening Techniques for Disease Resistance in Faba Bean. International Centefo Agricultural Reseach in the dry Areas (ICARDA). Aleppo, Syria. $59 \mathrm{pp}$.

Hawkes, J.G. 1994. The Potato Evolution, Biodiversity and Genetic Resources. Blhaven Press, London, 259pp.

Hilal, A.; Nada, M.G.A. and Zaky, W.H. 2006. Induced resistance against disease in some umbelliferous medicinal plants as possible and effective control men. Egypt. J. Phytopathol., 34(2): 85-101.

Jensen, B.J.L.; Preece, S.J.; Lamothe, M.; Pearce, N.J.G.; Froese, D.G.; Westgate, J.A.; Schaefer, J.; Begét, J. 2011. The variegated (VT) tephra: A new regional marker for middle to late marine isotope stage 5 across Yukon and Alaska: Quaternary International, 246: 312-323.

Lenc, L.; Łukanowski, A. and Sadowski, Cz. 2008. The use of PCR amplification in determining the toxigenic potential of Fusarium sambucinum and F. solani isolated from potato tubers with symptoms of dry rot. Phytopathol. Pol., 48: 1323.

Liu, L.; Kloepper, J.W.; and Tuzun, S. 1995. Induction of systemic resistance in cucumber against Fusarium wilt by plant growth-promoting rhizobacteria. Phytopathology, 85: 695-698.

Lui, L.H. and Kushalappa, A.C. 2002. Response surface models to predict potato tuber infection by Fusarium sambucinum from duration of wetness and temperature, and dry rot lesion expansion from storage time and temperature. International J. Food Microbiol., 76: 19-25.

Mansour, F.S and Naffa, A.M.A. 2005. Effect of modified and controlled atmospheres on finger rot Botryodiplodia theobromae and quality of "Williams" Banana Fruits. Minufiy. J. Agric. Res., 30(2): 409-424.

Mohammadi. R.S. 2012. Effect of essential oils on postharvest decay and some quality factors of peach (Prumus persica var. pedhaven). Journal of Biodevirsty and Environmental Sciences, 6: 147-153.

Egypt. J. Phytopathol., Vol. 47, No. 1 (2019) 
Morsy, A.A.; Abd-El-Kareem F. and Abd-Alla, M.A. 2000. Effect of acetic acid fumigation on common storage fungi of some grains, Egypt. J. Phytopathol., 26: 95-106.

Naffa, A.M.A. 1995. Pollution of dates by postharvest pathogens M.Sc. Institute of Environmental Studies and Researches., Ain Shams University. Pp166.

Naffa, A.M.A. 2012. Control of dry rot disease on potato during storage. Egypt. J. Phytopathol., 40(1): 29-40.

Naffa, A.M.A.; Mansour, F.S. and Soltan, H.H.M. 2006. Effect of antioxidants on postharvest fungal diseases of exported cantaloupe fruits. Annals Agric. Sci., 51(1): 247-258.

Panahirad, S.; Zaare-Nahndii, F.; Safaralizadeh, R. and Alizadeh-Salteh, S. 2012. Postharvest control of Rhizopus stolonifer in peach (Prunus persica L. Batsch) fruits using salicylic acid. Journal of Food Safety, 32: 502-507.

Rashied. D.I.S. 2008. Studies on Fungal Post Harvest Diseases of Potatoes Prepared for Exportation and Processing. Ph.D. Thesis, Fac. Agric., AL-Azhar Univ. $244 \mathrm{Pp}$.

Samane, M. and Aminifard, M.H. 2012. Effect of essential oils on postharvest decay and some quality factors of peach (Prunus persica var. Redhaven ). J. Biol. Environ. Sci., 6(17): 147-153.

Secor, G.A.; Preston, D.A.; Gudmestad, N.C. and Lamey, H.A. 1992. Fusarium dry Rot. Extension Service, North Dakota State Univ. Agr. Appl. Sci., Pp.1039.

Siviero, P. and Motton, M.S. 2000. The enemies of the narrow. Informatore Agrario, 56(16): 39-49.

Song, W. and Keane, A.J. 2006: "Parameter Screening Using Impact Factors and Surrogate- Based ANOVA Techniques", AIAA-2006-7088, 11 ${ }^{\text {th }}$ AIAA/ISSMO Multidisciplinary Analysis and Optimization Conference, Renaissance Portsmouth, Portsmouth, Virginia, 6-8 Sep 2006.

Vitale, S.; Luongo, L. and Corazza, L. 1999. Molecular characterization of Fusarium solani from potato. Massimo Zaccardelli Istituto Sperimentale per le Colture Industriali, Mi.P.A,. Strada Statale 18: 156, I-84091 Battipaglia (Salerno), Italy.

Corresponding author: Attia, M.F

E-mail: attiamf@gmail.com

(Received 09/03/2019;

in revised form 30/03/2019) 


\section{مقاومة أعفان درنات البطاطس باستخدام بعض الاحماض العاض الزئل

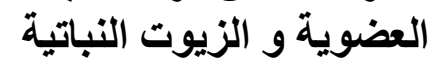

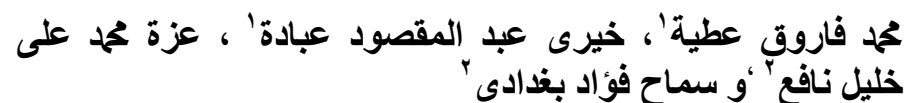

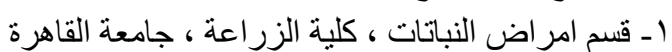

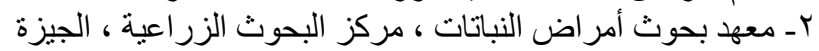

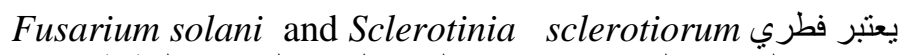

التى تسبب بالترتيب العفن الابيض و العفن الجاف لدرنات البطاطس هما

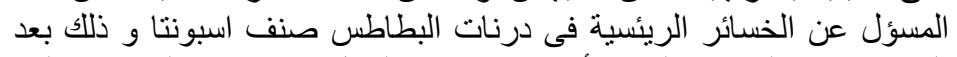

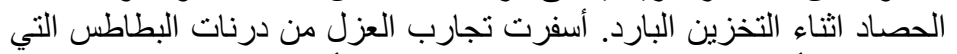

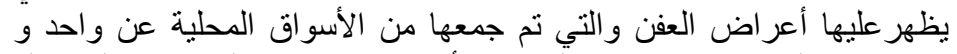

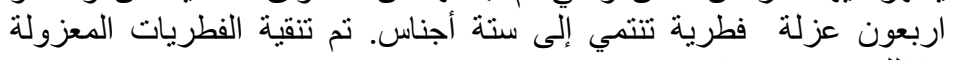

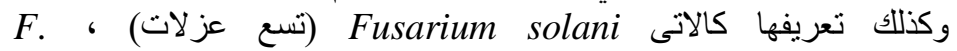

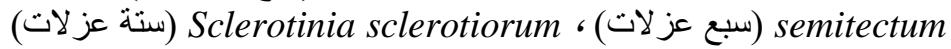

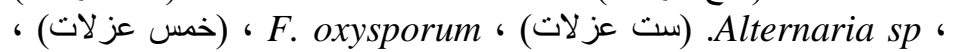
Rhizoctonia solani

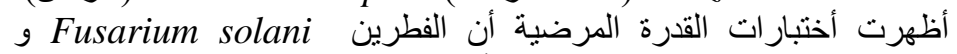
Sclerotinia sclerotiorum

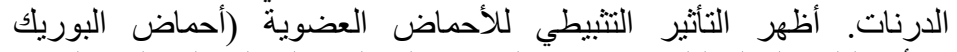

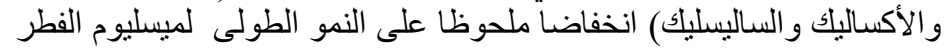

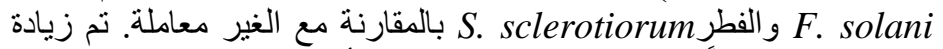

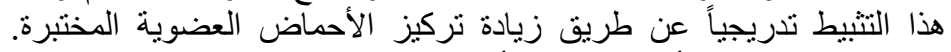





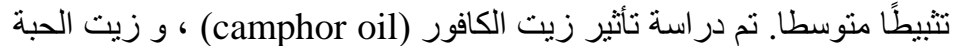





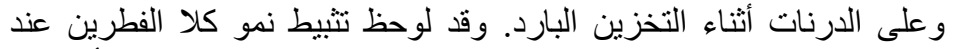

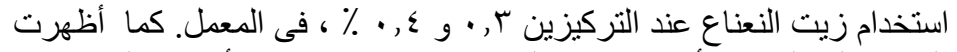

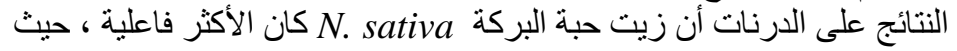



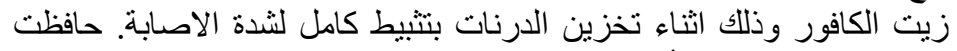

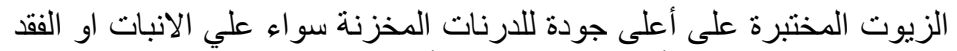

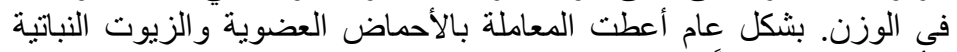

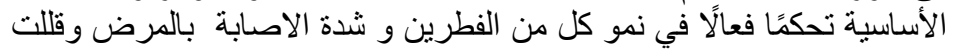

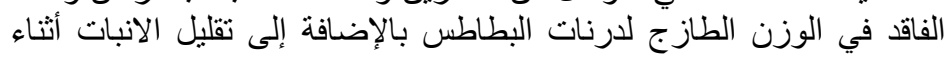
التخزين البارد عند سا ال درجة لمئوية لمدة شهرين.

Egypt. J. Phytopathol., Vol. 47, No. 1 (2019) 